Ritrýnd grein birt 31. desember 2019

\title{
Dátttaka nemenda í kennslustundum í framhaldsskólum á Íslandi
}

\author{
Hafrún Hafliðadóttir, Elsa Eiríksdóttir og Ingólfur Ásgeir Jóhannesson
}

Abstract

Um höfundana

About the authors

Heimildir

Rannsökuð var pátttaka nemenda í kennslustundum í níu íslenskum framhaldsskólum og var markmið prípæett. Í fyrsta lagi að greina hvernig pátttaka nemenda birtist í kennslustundum. Í öðru lagi að skoða hvort kennsluaðferðirnar í peim kennslustundum par sem pátttaka nemenda var til staðar væru kennarastýrðar eða nemendamiðaðar. Í priðja lagi að skoða viðmót og athafnir kennara í kennslustundum par sem nemendur tóku pátt. Unnið var úr 130 vettvangslýsingum á kennslustundum í níu framhaldsskólum sem safnað var á skólaárinu 2013-2014 og haustið 2014 í rannsóknarverkefninu Starfshættir í framhaldsskólum. Kennslustundir voru flokkaðar eftir pví hvort pær náðu viðmiðum um pátttöku. Viðmiðið var að $75 \%$ af nemendunum tækju pátt í pví sem kennarinn ætlaðist til af peim í 75\% af tímanum og náðu 83 kennslustundir pessu viðmiði. Algengustu birtingarmyndir pátttöku nemenda í kennslustundum voru að peir unnu verkefni og spurðu kennara um námsefnið og komu pessar athafnir fram í meirihluta kennslustundanna. Í um helmingi stundanna kom einnig fram að nemendur sýndu athygli (fylgdust með) og ræddu um viðfangsefnið. Niðurstöður benda til pess að pátttaka nemenda í kennslustundum tengist ekki hvaða kennsluaðferðir eru notaðar, par sem pátttökustundirnar skiptust frekar jafnt í nemendamiðaðar og kennarastýrðar kennslustundir. Flestar birtingarmyndir pátttöku nemenda komu tiltölulega jafnt fyrir í bæði kennarastýrðum og nemendamiðuðum kennslustundum en athöfnin að sýna athygli var algengari í kennarastýrðum kennslustundum og athafnirnar að leita og nota efnivið og hjálpast að við að leysa verkefni komu oftar fram í nemendamiðuðum kennslustundum. Flestar pátttökustundanna einkenndust af pví að kennari sýndi jákvætt viðmót, hafði skapað hlýlegt andrúmsloft, hafði gefið skýr fyrirmæli um vinnu nemenda eða verið hvetjandi. Pannig virðast viðmót og athafnir kennara hafa haft jákvæð áhrif á pátttöku nemenda í kennslustundunum. Niðurstöðurnar undirstrika að mikilvægt er að gefa viðmóti og athöfnum kennara sérstakan gaum í samhengi við námslega skuldbindingu nemenda.

Efnisorð: Framhaldsskóli, pátttaka nemenda, skuldbinding, kennsluaðferðir, viðmót kennara

\section{Inngangur}

Dað sem nemendur gera í kennslustund frá degi til dags og pátttaka peirra í pví sem par fer fram ræður meðal annars pví sem lært er (Greenwood, Horton og Utley, 2002). Rannsóknir benda til pess að pátttaka nemenda í kennslustund tengist betri námsárangri og námsframvindu en einnig öðrum breytum sem hafa áhrif á gengi í námi, svo sem áhugahvöt og námsfærni (App- 
leton, Christenson og Furlong, 2008; DiPerna, Volpe og Elliott, 2001; Gettinger og Seibert, 2002; Greenwood o.fl., 2002; Kristjana Stella Blöndal og Sigrún Aðalbjarnardóttir, 2012, 2016; Rumberger, 2004). Markmið rannsóknarinnar er að athuga hvað einkennir kennslustundir í framhaldsskólum par sem nemendur taka pátt í pví sem kennarinn æetlast til, með pað fyrir augum að greina sérstaklega með hvaða hætti pátttaka nemenda birtist í kennslustundum, hvaða kennsluaðferðum var beitt og hvað einkenndi viðmót og athafnir kennara. Við rannsóknina voru notaðar vettvangslýsingar úr kennslustundum sem safnað var í rannsókn á starfsháttum framhaldsskóla á Íslandi par sem níu framhaldsskólar voru heimsóttir á tímabilinu 2013-2014.

\section{Skuldbinding til náms}

Hugtakið skuldbinding nemenda til náms og skóla nær yfir vítt svið, vísar til hegðunarlegra, tilfinningalegra og vitsmunalegra pátta og snýr jafnt að námi, félagslífi og skólanum í heild (Fredricks, Blumenfeld og Paris, 2004). Aukin skuldbinding nemenda til náms og skóla tengist betra gengi í skóla og meiri líkum á að nemendur tileinki sér jákvæða námshegðun sem nýtist peim ævilangt en skortur á skuldbindingu nemenda tengist auknum líkum á brotthvarfi frá skóla (Fredricks o.fl., 2004; Kristjana Stella Blöndal og Sigrún Aðalbjarnardóttir, 2012, 2016; Rumberger, 2004; Sinatra, Heddy og Lombardi, 2015; Taylor og Parsons, 2011).

Hegðunarleg skuldbinding (e. behavioral engagement) kemur fram í pátttöku og virkni nemandans. Degar barn eða unglingur tekur virkan pátt í kennslustund, vinnur heimavinnuna sína og fer eftir reglum sem skólinn setur sýnir pað góða hegðunarlega skuldbindingu (Fredricks o.fl., 2004; Skinner og Belmont, 1993). Hugtakið hefur pannig verið notað til að vísa til margra ólíkra pátta, allt frá pátttöku í kennslustund að virkni í félagslífi skólans, og er pví ansi víðtækt.

Hugtakið námsleg skuldbinding (e. academic engagement) vísar til tilgreindrar hegðunar nemenda í kennslustund sem hefur jákvæð tengsl við námsárangur (Greenwood o.fl., 2002; Schmidt, Rosenberg og Beymer, 2018). Pannig er átt við að nemendur taki pátt í vinnu á viðeigandi hátt miðað við pað sem fyrir er lagt, til dæmis með pví skrifa eða reikna, sýna kennara og samnemendum athygli og biðja um aðstoð. Rannsóknir hafa sýnt að nálgun kennara og val á aðferðum hafi áhrif á námslega skuldbindingu nemenda (Greenwood, Terry, Marquis og Walker, 1994).

Skiptar skoðanir eru um hvort námsleg skuldbinding heyri undir hegðunarlega skuldbindingu. Eins eru rannsakendur ekki sammála um hvort hugtakið námsleg skuldbinding eigi einungis við hegðun eða nái einnig yfir hugræna og tilfinningalega pætti (Al-Hendawi, 2012; Appleton, Christenson, Kim og Reschly, 2006; Sheppard, 2011). Í pessari rannsókn er áhersla lögðá námslega skuldbindingu, eins og hugtakið er skilgreint hér að ofan. Sjónum er beint sérstaklega að námslegri skuldbindingu með hliðsjón af pví hvort nemendur taki pátt í pví sem kennarinn ætlast til. Ef nálgun kennara hefur áhrif á námslega skuldbindingu nemenda er mikilvægt að skoða viðmót kennara og val á kennsluaðferðum í peim kennslustundum par sem nemendur taka pátt í pví sem til er ætlast. Eins hafa rannsóknir á námslegri skuldbindingu gjarnan farið fram á grunnskólastigi og pví er áhugavert að skoða hvernig pátttaka nemenda í kennslustundum birtist á framhaldsskólastigi.

\section{Birtingarmyndir pátttöku nemenda}

Skuldbinding nemenda er oft metin með pví að fylgjast með peim í kennslustund og pannig áætluð út frá hegðun peirra (Fredricks og McColskey, 2012). Oft er talað um námshegðun (e. academic responding) pegar vísað er í hegðun sem sýnir pátttöku í verkefnum, til dæmis að skrifa, rétta upp hönd, lesa upphátt, svara spurningum eða sýna einhverju athygli (Greenwood o.fl., 2002; Spanjers, Burns og Wagner, 2008). Birtingarmynd pátttöku nemenda í kennslustund fer eftir pví til hvers kennarinn ætlast. Í grófum dráttum mætti segja að kennari æetlist annars vegar til pess að nemendur séu aðgerðarlausir og sýni einhverju athygli eða hins vegar að peir geri eitthvað og fari eftir fyrirmælum (Corrodi, Vogt og Heim, 2019). Á sama hátt geta nemendur 
brugðist við með pví að vera aðgerðarlausir eða með pví að gera eitthvað. Ef kennarinn ætlast til athygli nemenda, til dæmis pegar haldinn er fyrirlestur eða kennt er við töflu, pá er nemandi að gera pað sem til er ætlast ef hann fylgist með. Pannig er aðgerðarlaus nemandi sem sýnir athygli og fylgist með í reynd pátttakandi í kennslustundinni. Að sama skapi, ef kennarinn æetlast til að nemandi geri eitthvað, til dæmis leysi verkefni eða taki pátt í umræðum, pá er nemandi að gera pað sem til er ætlast ef hann sést taka pátt í peirri vinnu. Af pessu má sjá að mat á pátttöku nemenda í kennslustund, eins og hún er skilgreind hér, er alltaf bundið pví til hvers kennarinn æetlast og peim kennsluaðferðum sem notaðar eru hverju sinni.

\section{Kennsluaðferðir og pátttaka nemenda}

Val á kennsluaðferðum er einn sá páttur sem skiptir máli fyrir pátttöku nemenda í kennslustundum pví pær geta haft mikil áhrif á áhuga nemenda og skilning á viðfangsefninu, sem og pað nám sem á sér stað (Hattie, 2009; Sigrún Aðalbjarnardóttir, 2016). Kennsluaðferð (e. teaching method) er hugtak sem notað er yfir pað skipulag sem kennarinn leggur upp með í sinni kennslu, samskiptin sem hann á við nemendur, viðfangsefnin sem hann notar og pað námsefni sem hann kýs að kenna (Burden og Byrd, 2016; Ingvar Sigurgeirsson, 2013). Kröfur um fjölbreytni í kennslu og kennsluaðferðum hafa aukist á síðustu árum og í Aðalnámskrá framhaldsskóla er lögð áhersla á fjölbreytni í vinnubrögðum og kennsluaðferðum til ,að nemendur öðlist margvíslega hæfni“ (Mennta- og menningarmálaráđuneytið, 2011, bls. 29).

Til eru margar leiðir til pess að flokka kennsluaðferðir, en algeng og einföld flokkun er að skipta peim í kennarastýrðar (e. teacher-centered, teacher-directed, teacher-focused) og nemendamiðaðar kennsluaðferðir (e. student-centered, student-focused), sbr. hugtakanotkun sem birtist hjá Ingvari Sigurgeirssyni, Elsu Eiríksdóttur og Ingólfi Ásgeiri Jóhannessyni (2018). Kennarastýrðar aðferðir einkennast af pví að kennarinn er í forgrunni og snýst kennslan um hvað hann gerir til að miðla efninu til nemenda, til að mynda með fyrirlestrum, sýnikennslu og skriflegum eða verklegum æfingum (Burden og Byrd, 2016; Cuban, 2007; Freiberg og Driscoll, 2000; Ingvar Sigurgeirsson, 2013). Nemendamiðaðar kennsluaðferðir byggjast hins vegar á virkni nemenda, er áherslan á nám nemenda og hvernig hægt er að styðja við upplýsingaöflun peirra. Algengar aðferðir eru lausnaleitarnám (e. problem-based instruction) og uppgötvunarnám (e. discovery learning). Pannig stýrir kennarinn ekki nemendum í tiltekna átt heldur leita nemendur upplýsinga og komast að eigin niðurstöðu.

Rannsóknir hafa sýnt að kennarar nota oftar kennarastýrðar aðferðir en nemendamiðaðar (Fisher, 2009; Juuti, Lavonen, Uitto, Byman og Meisalo, 2010; Pianta, Belsky, Houts og Morrison, 2007). Rannsóknir á kennsluaðferðum í íslenskum framhaldsskólum ber að sama brunni, en algengustu aðferðirnar í peim, til dæmis fyrirlestrar, sýnikennsla eða vinna með vinnubækur og námshefti, teljast kennarastýrðar aðferðir (Ingvar Sigurgeirsson o.fl, 2018; Svanhildur Kr. Sverrisdóttir, Ragnheiður Margrét Guðmundsdóttir og Sigurlína Davíðsdóttir, 2011). Kennsluaðferðir sem flokkast undir nemendamiðaðar virðast síður notaðar prátt fyrir umræðu um að pær séu áhrifaríkar til að virkja nemendur í kennslustundum og að nemendur kjósi pær frekar (Bolinger og Warren, 2007; Braičić, Đuranović og Klasnić, 2014; Ingvar Sigurgeirsson o.fl., 2018; Juuti o.fl., 2010; Taylor og Parsons, 2011).

Рað má pví leiða líkur að pví að hvort kennsluaðferð sé kennarastýrð eða nemendamiðuð hafi áhrif á pað hvernig pátttaka nemenda í kennslustundum birtist. Kennarastýrðar aðferðir eru ekki slæmar aðferðir, en pær geta takmarkað fjölbreytta pátttöku nemenda par sem margar kalla fyrst og fremst á að nemendur hlusti og fylgist með kennara. Rannsóknir hafa gefið til kynna að námsleg skuldbinding nemenda í kennslustund sé minni pegar um fyrirlestra og einstaklingsverkefni er að ræða og að opnari verkefni í samvinnu auki líkur á námslegri skuldbindingu, en tryggi hana pó ekki (Schmidt o.fl., 2018). 


\section{Viðmót og athafnir kennara}

Rannsóknir hafa sýnt tengsl á milli sambands kennara við nemendur og skuldbindingar nemenda til náms (Roorda, Koomen, Spilt og Oort, 2011; Rosenfeld, Richman og Bowen, 2000; Voelkl og Frone, 2000). Framkoma og virðing kennara gagnvart nemendum, og sú upplifun að gengi í námi og viðvera í tímum skipti kennara máli eykur skuldbindingu nemenda til námsins (Bempechat og Shernoff, 2012; Li, Lynch, Kalvin, Liu og Lerner, 2011; Murdock, 1999; Roorda o.fl., 2011; Taylor og Parsons, 2011). Einnig skiptir máli að kennarar séu samkvæmir sjálfum sér, hafi skýrar væntingar til nemenda sinna og hvetji pá áfram (Skinner og Belmont, 1993). Nemendur sem upplifa litlar kröfur frá kennara eru líklegri til að hverfa frá námi prátt fyrir góðan námsárangur, og eins getur skortur á hlýlegu viðmóti og hvatningu frá kennara dregið úr áhuga peirra (Hafsteinn Karlsson, 2009; Murdock, 1999). Rannsóknir hafa líka sýnt að samband nemenda og kennara sem einkennist af umhyggju, áhuga og gagnkvæmri virðingu geti haft jákvæð áhrif á sjálfsmynd, sjálfsöryggi og prautseigju nemenda (Dunleavy og Milton, 2009). Að lokum benda rannsóknir einnig til pess að samband kennara og nemenda verði mikilvægara og hafi meiri áhrif á skuldbindingu peirra pví eldri sem peir eru og sömuleiðis ef nemendur búa við erfiðar aðstæður (Pianta, Steinberg og Rollins, 1995; Roorda o.fl., 2011).

Á heildina litið gefa rannsóknir pví til kynna að pegar kennarar skapa umhverfi sem stuðlar að jákvæðum samskiptum, par sem brugðist er við pörfum nemenda og hlúð er að námssamfélagi, pá verða nemendur jákvæðari gagnvart skólanum, náminu og kennaranum og líklegri til að sýna jákvæða námshegðun, hafa áhuga á pví sem fram fer í skólanum og upplifa sig sem hluta af nemendahópnum (Appleton o.fl., 2008; Fredricks o.fl., 2004; Li og Lerner, 2011; Reyes, Brackett, Rivers, White og Salovey, 2012). Viðmót kennara og pað andrúmsloft sem peir skapa í skólastofunni getur pví skipt sköpum fyrir skuldbindingu nemenda og stuðlað að betri námsárangri.

\section{Markmið og rannsóknarspurningar}

Í pessari rannsókn var ákveðið að skoða sérstaklega kennslustundir par sem nemendur tóku pátt í pví sem kennarinn æetlaðist til. Slíkar kennslustundir teljast vera dæmi um árangursríkar kennslustundir par sem kennaranum tekst ætlunarverk sitt og pví er áhugavert að skoða nánar hvað einkennir pær. Notuð voru vettvangsgögn úr 130 kennslustundum í íslenskum framhaldsskólum (Gerður G. Óskarsdóttir og rannsóknarhópur um starfshætti í framhaldsskólum, 2018). Rannsóknarspurningarnar eru prjár: (1) Hvernig birtist pátttaka nemenda í kennslustundum? (2) Beittu kennarar í pessum kennslustundum kennarastýrðum eða nemendamiðuðum kennsluaðferðum? (3) Hvað einkenndi viðmót og athafnir kennara í kennslustundum?

\section{Аðferð}

\section{Gagnasafnið}

Vettvangslýsingunum var safnað í rannsókninni Starfshættir í framhaldsskólum í níu ólíkum framhaldsskólum sem valdir voru með lagskiptu úrtaki (Gerður G. Óskarsdóttir o.fl., 2018). Rannsakendur fylgdust með alls 130 kennslustundum í ólíkum námsgreinum á skólaárinu 20132014 og haustið 2014 og skráðu pað sem fram fór. [1] Val kennslustunda fór pannig fram að dregin voru af handahófi út nöfn bekkja í bekkjarskólum eða nemenda í áfangaskólum til að fylgja eftir yfir skóladaginn (án vitundar nemendanna sem fylgt var). Reynt var að dreifa vettvangsathugunum á ólíkar námsbrautir og pví var í sumum tilvikum hentivali beitt til að tryggja fjölbreytni. Kennslustund var hér skilgreind sem sú eining sem skóli hafði ákveðið að væri ein heild og kennari skipulagði pannig. Í sumum tilvikum voru pó frímínútur teknar meðan á kennslustund stóð. Samtals var fylgst með kennslu í 167 klukkustundir og var pví meðallengd hvers áhorfs 83 mínútur. Stysta kennslustundin sem fylgst var með varði í 27 mínútur en sú lengsta í fjórar klukkustundir og 24 mínútur. Um 82\% peirra voru á bilinu 40-80 mínútur. 
Rannsakendurnir héldu til haga fjölmörgum skráningum um kennslustundina, meðal annars um kennsluaðferðir, samskipti kennara og nemenda, framkomu kennara, námsgögn og miðla, upplýsingatækni, ástundun nemenda og hugleiðingar athugenda. Einn eða tveir rannsakendur fylgdust með hverri kennslustund og skráðu í tímasetta dálka hvað kennari og nemendur gerðu. Aftast á skrásetningarblađinu voru sérstakir reitir sem kölluðust kennslustundin í hnotskurn og hugleiðingar athuganda. Dar komu fram upplýsingar um megininntak kennslustundarinnar, virkni nemenda, kennsluaðferðir, nálgun kennara og athugasemdir rannsakenda um andrúmsloft, valdatengsl og lýðræði í kennslustofunni.

\section{Flokkun pátttökustunda}

Fyrsta skrefið í pessari rannsókn var mat á pví hvort nemendur hefðu tekið pátt í pví sem kennari ætlaðist til og var viðmið sett að 75\% nemenda tækju pátt í a.m.k. 75\% tímans. Vettvangslýsingarnar voru lesnar og kennslustundirnar 130 flokkaðar í prjá meginflokka: (1) pátttökustundir, par sem nemendur tóku pátt í pví sem kennarinn ætlaðist til, (2) kennslustundir sem náðu ekki viðmiðum um pátttöku nemenda og (3) kennslustundir bar sem skráning var ekki nægilega ítarleg til að geta sagt til um раð með vissu hvort kennslustundin uppfyllti viðmið. Dar sem stundir í síðari flokkunum tveimur reyndust fáar og vegna pess að eingöngu var ætlunin að greina pátttöku en ekki pátttökuleysi, var ekki alltaf greint vandlega á milli síðari flokkanna tveggja.

Flokkunin fór pannig fram að upphaflega var valið úrtak sjö kennslustunda úr hverjum skóla, alls 63 kennslustundir, sem tveir höfundanna flokkuðu út frá viðmiðinu um að 75\% nemenda væru að gera pað sem kennari ætlast til 75\% tímans. Í byrjun fóru pau bæði yfir 21 kennslustund, leystu álitamál og samræmdu flokkun og skilning. Síðan flokkuðu pau hvort fyrir sig 21 kennslustund en ef vafamál komu upp fóru bæði yfir kennslustundina. Priðji höfundurinn bættist í hópinn að pessu loknu og flokkaði hinar 67 stundirnar eftir að hafa sett sig inn í hvernig flokkað var. Álitamál voru leyst með pví að tveir fóru yfir kennslustundina en pað var í 15 kennslustundum og auk pess var farið tilviljunarkennt yfir nokkrar lýsingar úr safninu til að tryggja að allir matsmenn mætu pær eins.

Alls voru 83 kennslustundir flokkaðar sem pátttökustundir eftir petta ferli og voru pær úr öllum níu skólunum, fæstar tvær og flestar fjórtán - en vegna pess að heildarfjöldi vettvangslýsinga var misjafn eftir skólum og pess hvernig úrtak var valið, bæði á vettvangi og í vinnunni við pessa grein, er ekki hægt að alhæfa um skólana í pessu samhengi. Viðfangsefni pátttökustundanna voru fjölbreytt, allt frá hefðbundnum námsgreinum eins og stærðfræði og dönsku að óhefðbundnari greinum eins og lífsleikni og kynjafræði.

\section{Greining á pátttöku nemenda}

Næsta skref rannsóknarinnar fólst í pví að greina hvernig pátttaka nemenda birtist. Til pess að gera pað var stuðst við hluta af greiningarkerfi til að meta námslega skuldbindingu nemenda í kennslustundum (Greenwood, Carta, Kamps, Terry og Delquadri, 1994; Greenwood o.fl., 2002; Institute on Community Integration, 2006). Í greiningarkerfinu eru tveir undirflokkar, námshegðun (e. academic responding) og verkefnastjórnun (e. task management) sem eiga sérstaklega við athafnir nemenda 1 kennslustundum. Eftirfarandi athafnir nemenda voru greindar til að skoða hvernig pátttaka peirra birtist í kennslustundunum: Að skrifa (glósa), vinna verkefni, lesa (í hljóði eða upphátt), hjálpast að, ræða um viðfangsefni, spyrja kennara spurninga, biðja um aðstoð frá kennara, sýna athygli (hlusta og fylgjast með), svara spurningum kennara, leita og nota efnivið og sýna áhuga á ýmsa vegu. Skrád var hvert skipti sem pessar athafnir birtust í lýsingunum á kennslustundum. Degar byrjað var að greina gögnin kom fyrir skörun á milli ólíkra virkniathafna (til dæmis hvort flokka ætti pað að skrifa í verkefnabók sem að vinna verkefni eða skrifa) og pví ákveðið var að prengja skilgreiningar á peim athöfnum par sem skörunin var algengust til að athöfn væri ekki talin til tveggja mismunandi flokka. 
Hver athöfn var aðeins skráð einu sinni í hverri kennslustund prátt fyrir að hún kæmi oftar fram. Pannig fékk tiltekin athöfn gildið 1 í gagnagrunninum ef hún kom fram í kennslustund, óháð pví hversu lengi var unnið á pann hátt eða hversu oft hún kom fyrir í kennslustundinni. Kennslustund gæti pví mest talist með 11 gildi par sem pað voru 11 athafnir til greiningar. Detta var að hluta til gert par sem vettvangslýsingar voru mjög ólíkar innbyrðis, sérstaklega með tilliti til pess hversu ítarlega hegðun nemenda og kennara var skráð og nákvæm tímasetning hegðunar var.

\section{Greining á kennsluaðferðum}

Priðja skref rannsóknarinnar fólst í pví að kennsluaðferðir í hverri pátttökustund voru flokkaðar í kennarastýrðar eða nemendamiðaðar aðferðir. Notuð var flokkun úr Litrófi kennsluaðferðanna (Ingvar Sigurgeirsson, 2013) og byggt á greiningu Ingvars Sigurgeirssonar o.fl. (2018), par sem allar kennsluaðferðir sem var beitt í kennslustundunum (heildarsafninu, 130 stundum) voru flokkaðar. Í greiningunni fyrir pessa rannsókn voru kennsluaðferðir í hverri pátttökustund skoðaðar og kennslustundin flokkuð sem kennarastýrð eða nemendamiðuð. Í pessu tilviki var miðað við að 80\% af stundinni einkenndist annaðhvort af kennarastýrðum eða nemendamiðuðum kennsluaðferðum og féllu flestar kennslustundanna fremur augljóslega í annan hvorn pessara flokka.

Kennarastýrðar kennsluaðferðir eru samkvæmt Litrófi kennsluaðferðanna meðal annars bein kennsla, útlistunarkennsla, pulunám og pjálfunaræfingar, verklegar æfingar og umræðu- og spurnaraðferðir. Par hefur kennarinn meiri stjórn á hvernig unnið er að pví að ná peirri pekkingu fram sem ætlast er til af nemendum í kennslustundinni. Nemendamiðaðar kennsluaðferðir eru meðal annars innlifunaraðferð og tjáning, prautalausnir, leitaraðferðir, hópvinnubrögð og sjálfstæð og skapandi viðfangsefni. Pær kennslustundir par sem nemendur hlustuðu á fyrirlestra eða unnu í vinnubókum voru til dæmis flokkaðar sem kennarastýrðar en par sem peir höfðu meiri stjórn, leituðu að efni sjálfir og kennarinn var meira til staðar til að leiðbeina, flokkuðust sem nemendamiðaðar.

Sumar kennslustundir voru skipulagðar með blönduðum aðferðum og voru pá flokkaðar sem blandaðar kennslustundir. Detta voru til dæmis kennslustundir sem byrjuðu með fyrirlestri um ákveðið efni og síðan áttu nemendur að auka pekkingu sína sjálfir eða dýpka skilninginn og leysa skapandi verkefni um ákveðið viðfangsefni. Eins kom fyrir að ekki var nógu skýrt í lýsingu á kennslustund hvort um var að ræða kennarastýrðar eða nemendamiðaðar kennsluaðferðir og voru pær kennslustundir einnig flokkaðar sem blandaðar.

\section{Greining á viðmóti og athöfnum kennara}

Loks voru vettvangslýsingarnar greindar með hliðsjón af viðmóti og athöfnum kennara. Farið var yfir lýsingar á viðmóti og athöfnum kennara og efnið pemagreint. Вæði var stuðst við lýsingar á pví sem gerðist í kennslustundinni, hvað kom fram í reitunum kennslustundin í hnotskurn og hugleiðingar athuganda á skráningarblöðum. Fjögur pemu komu fram við pessa greiningu: Jákvætt viðmót, hlýlegt andrúmsloft, skýr fyrirmæli og hvetjandi kennari. Jákvætt viðmót kennara birtist til dæmis í pví að taka vel á móti nemendum pegar peir komu inn í kennslustundina. Hlýlegt andrúmsloft vísaði til dæmis til beinna og óbeinna aðgerða, til pess fallinna að skapa vinnufrið og vellíðan. Driðja pemað fólst í að fyrirmæli kennara væru skýr. Fjórða pemað, hvetjandi kennari, birtist meðal annars í pví að kennarar hrósuðu nemendum og gerðu kröfur til peirra (nánari útlistun á pemunum kemur fram í niðurstöðukafla). Kennslustundir voru flokkaðir í pemaflokk ef pað sem pótti einkenna pemað kom fram í kennslustundinni. Önnur atriði, par með taldir neikvæðir pættir, komu miklu sjaldnar fram og urðu pannig ekki að pemum sem hægt var að fjalla um.

\section{Styrkleikar, veikleikar og trúnaður}

Styrkleikar gagnasafnsins í heild fólust annars vegar í hversu ítarlegar og efnismiklar vettvangslýsingarnar voru og hins vegar að $44 \%$ peirra voru skráđar af tveimur rannsakendum. Í pessum 
kennslustundum sátu reyndir rannsakendur og nemendur í doktors- og meistaranámi saman kennslustundir og skráđu. Auk pess skiptust rannsakendur á að vinna saman og álitamál um skráninguna voru rædd jafnóðum á fundum rannsóknarhópsins (Gerður G. Óskarsdóttir o.fl., 2018).

Lýsingar á kennslustundum voru misítarlegar en í langflestum tilvikum var skráning á framvindu hverrar stundar nógu nákvæm til að meta pátttöku nemenda og sjá hvers konar kennsluaðferðum var beitt. Upplýsingar um viðmót og athafnir kennaranna eru byggðar á huglægu en faglegu mati rannsakendanna og annaðhvort skráðar strax eða mjög fljótt á eftir í reitina um kennslustundina í hnotskurn og athugasemdir rannsakanda. Greiningin á viðmóti og athöfnum kennara var ekki hluti af upphaflegri rannsóknaráætlun verkefnisins og pví var gögnunum ekki safnað með pessa greiningu sérstaklega í huga. Dað takmarkar ályktunargildi, sérstaklega par sem hugtök á borð við viðmót og andrúmsloft höfðu ekki verið fyrir fram skilgreind. Viðmót og andrúmsloft eru pó skýr dæmi úr orðræðu um kennslufræði og við lestur gagnanna kom fram að jákvætt viðmót og hlýlegt andrúmsloft virðast hafa verið nokkuð skýr fyrirbæri í hugum peirra sem skráðu.

Trúnaðar gagnvart nemendum, kennurum og skólum, sem pátt tóku hefur verið gætt og ekki eru birtar upplýsingar sem hægt er að rekja til ákveðinna skóla eða kennara.

\section{Niðurstöður}

Í fyrsta hlutanum er farið yfir hvernig pátttaka nemenda birtist í kennslustundunum. Síðan er farið yfir flokkun kennsluaðferða í kennarastýrðar eða nemendamiðaðar. Að lokum er fjallað um viðmót og athafnir kennara.

\section{Birtingarmyndir pátttöku í kennslustundum}

Í Töflu 1 er yfirlit yfir pær athafnir nemenda sem komu fram í kennslustundunum 83, en í heildina voru 400 athafnir greindar. Að vinna verkefni og að spyrja kennara spurninga um námsefnið voru pær athafnir sem komu oftast fyrir og í meirihluta pátttökustunda. Sjaldgæfast var að nemendur læsu (í hljóði eða upphátt) og leituðu og notuðu efnivið.

Tafla 1. Tíðni athafna nemenda í pátttökustundum (kennslustundum par sem nemendur tóku pátt í pví sem kennari ætlaðist til). Einnig hlutfall pátttökustunda sem athöfnin kom fyrir í og hlutfall af heildarfjölda allra athafna.

\begin{tabular}{lccc}
\hline Athafnir nemenda (birtingarmynd pátttöku) & Tíðni $\begin{array}{c}\text { Hlutfall af } \\
\text { athöfnum } \\
(\boldsymbol{n}=\mathbf{4 0 0})\end{array}$ & $\begin{array}{c}\text { Hlutfall af } \\
\text { kennslustundum } \\
(\boldsymbol{n}=\mathbf{8 3})\end{array}$ \\
\hline Vinna verkefni & 69 & $17 \%$ & $82 \%$ \\
Spyrja kennara spurninga um námsefnið & 65 & $16 \%$ & $77 \%$ \\
Sýna athygli (hlusta, fylgjast með) & 46 & $12 \%$ & $55 \%$ \\
Ræða um viðfangsefnið (sín á milli eða við kennara) & 44 & $11 \%$ & $52 \%$ \\
Hjálpast að & 39 & $10 \%$ & $46 \%$ \\
Svara spurningum kennara & 38 & $10 \%$ & $45 \%$ \\
Biðja um aðstoð kennara & 35 & $9 \%$ & $42 \%$ \\
Skrifa (glósa) & 21 & $5 \%$ & $25 \%$ \\
Sýna áhuga á ýmsa vegu & 19 & $5 \%$ & $23 \%$ \\
Leita og nota efnivið (t.d. heimildaleit) & 15 & $4 \%$ & $18 \%$ \\
Lesa (í hljóði eða upphátt) & 9 & $2 \%$ & $11 \%$ \\
\hline Samtals & 400 & $100 \%$ & $100 \%$ \\
\hline
\end{tabular}


Nemendur unnu verkefni í meirihluta pátttökustundanna og var pví oftast lýst eins og hér kemur fram í kennslustund í íslensku: „Nemendur vinna, nokkuð hljótt í stofunni.“ Fjölbreytileiki verkefna var mikill og gat verið allt frá pví að vinna fyrirfram skipulagða vinnu í vinnubók í að vinna skapandi verkefni. Eins gat pað átt við bæði einstaklingsverkefni og hópavinnu, eins og til dæmis í kennslustund í ensku par sem nemendur pöruðu saman orð:

Allir í bekknum eru virkir að para saman. Pau tala saman um orðin, spyrja hvert annað hvað pau pýða, bæði ensk orð og íslensk orð. Fyrsti hópurinn er búinn að para saman öll orðin og tilkynnir pað. (Úr dálknum par sem athöfnum nemenda er lýst)

Miðað við fjölbreytileika í verkefnum er ekki að undra að athöfnin hafi verið sú algengasta.

Sú athöfn sem kom næst oftast fyrir var að spyrja kennarann spurninga um námsefnið. Að spyrja spurninga gat birst í pví að nemandi bað um frekari útskýringar, eins og til dæmis í stærðfræðitíma pegar nemandi spyr kennara „hvað strik fyrir ofan pýði“. Раð аð nemendur spyrji spurninga um námsefnið sé ein algengasta athöfnin hlýtur að teljast jákvætt pví pað sýnir að minnsta kosti að nemendur eru að spá í vinnuna sem fram fer í kennslustundinni, hversu djúp eða grunn sú hugsun kann að vera.

Að sýna athygli og ræða um námsefnið voru athafnir sem komu fram í um helmingi pátttökustundanna. Að sýna athygli (hlusta og fylgjast með) kom oftast fyrir í kennslustundum par sem kennari var með fyrirlestur, töflukennslu eða sýndi myndband. Detta gat staðið yfir alla kennslustundina eða aðeins hluta hennar og var pá yfirleitt verið að fást við verkefni í hinum hluta stundarinnar. Dæmigerðar lýsingar á pessari athöfn voru „,nemendur hlusta á kennara“ eða „,nemendur fylgjast með“, en eins komu fram nánari lýsingar eins og „,nemendur horfa á myndband af töluverðum áhuga, nokkrir strákar spjalla af og til saman sín á milli um efni kennslustundar“. Аð ræða um námsefnið kom annaðhvort fram með peim hætti að kennari stjórnaði umræðum í hópnum í heild eða að nemendur ræddu sín á milli í smærri hópum. Degar umræða var í hópum var oftast um einhvers konar skipulagða hópavinnu að ræða, eins og í eftirfarandi lýsingu á kennslustund í íslensku:

Nemendur eru í nokkrum smáhópum ... Allir eiga að ... útbúa verkefni sem tengist meginpema áfangans, en pau ráða alfarið hvernig pau útfæra pað. Nemendur tala um hvað pær geti gert, ein nefnir stað. Önnur nefnir íslenska fjárhundinn. [Aðrir] nemendur syngja lag sem peir eru að semja. (Úr dálknum par sem athöfnum nemenda er lýst)

Eins kom fyrir að nemendur ræddu um einstaklingsvinnu eða námsefni sín á milli án hvata eða aðkomu kennara.

Athafnirnar að hjálpast að, svara spurningum kennara og biðja um aðstoð kennara komu fram í tæplega helmingi pátttökustundanna. Pegar nemendur voru að hjálpast að átti pað oftast við pegar peir leystu verkefni, jafnvel einstaklingsverkefni. Stundum fengu nemendur val um hvort peir hjálpuðust að eins og í kennslustund í afbrotafræði:

Eftir fyrirlesturinn og umræðurnar setur kennarinn spurningar upp á skjáinn sem nemendur eiga að svara. Kennarinn gengur á milli og fylgist með og segir: Dað má vinna saman en að vinna saman pýðir ekki að skipta á milli sín spurningunum. (Úr dálknum par sem athöfnum kennara er lýst)

Í framhaldi á lýsingunni á kennslustundinni er prisvar tekið fram að flestir vinna en ,smá skvaldur í stofunni“" par sem hluti nemenda vann verkefnið saman. Að svara spurningum kennara kom oftast fram í upphafi eða lok kennslustunda, og var pá kennari gjarnan að athuga hvað nemendur vissu fyrir fram um tiltekið viðfangsefni, eða var að athuga hvort skilningur væri á efni kennslustundarinnar.

Að biðja um aðstoð kennara átti oftast við lýsingar á athöfnum par sem nemendur biðja kennara um að koma, annaðhvort til einstaka nemenda eða hóps nemenda sem vinnur saman. Pví er pessi 
athöfn ólík peirri að spyrja kennara spurninga að pví leytinu til að oftast pýðir pað að biðja um aðstoð að kennarinn kemur til nemenda. Hér eru dæmi úr kennslustund í náttúrulæsi par sem nemendur unnu skapandi ritunarverkefni: „Nemandi biður um hjálp“ og „,nemendur með hendur á lofti“", sem átti við um meirihluta kennslustundarinnar. Gjarnan virtist opið verkefni leiða til pess að nemendur kölluðu eftir aðstoð frekar en að spyrja spurninga yfir allan hópinn.

Að skrifa og að sýna áhuga kom fram í um fjórðungi allra pátttökustunda. Athöfnin að skrifa fólst langoftast í pví að nemendur glósuðu pegar kennarinn talaði uppi við töflu eða var með glærur á skjávarpa, til dæmis í kennslu í stærðfræði; „Nemendur pöglir og fylgjast með og skrifa niður af töflunni.“" Einnig kom fyrir að nemendur skrifuðu í stílabækur út frá verkefni eða unnu í vinnubók. Að sýna áhuga á ýmsa vegu gat falist í pví að nemendur beinlínis sögðu kennara frá pví að peim fyndist efnið áhugavert, en eins gat pað birst í gegnum athafnir nemenda, til dæmis pegar nemendur leituðu sér að efni út fyrir kennsluefni til að dýpka skilning sinn, eða unnu prátt fyrir hlé eða að tíma væri lokið. Dæmi um að sýna áhuga kemur úr kennslustund um tölvunotkun par sem athöfnum nemenda er lýst: „Nemendur eru áhugasamir og spyrja út í forritið. Vilja vita hvernig peir breyta myndum, eru áhugasamir að byrja." Eins kom fram að pegar kennari spurði nemendur hvort peir vildu taka stutta pásu: „Prjár stelpur svara neitandi og ein segir, petta er svo gaman."

Að leita og nota efnivið kom fram í um fimmtungi pátttökustunda og voru nemendur annaðhvort að leita að svörum við spurningum, til dæmis með vefleiðangri í lausnaleitarnámi, eða leita að heimildum. Einnig kom pessi athöfn fram í tímum í iðngreinum par sem nemendur áttu sjálfir að leita sér leiða til pess að leysa ákveðið verkefni. Að lesa kom sjaldnast fyrir, en pá áttu nemendur að lesa kennsluefni námskeiðsins. Stundum var petta í tengslum við sjálfstæð verkefni eins og í kennslustund í sögu par sem kennari bað nemendur að lesa frumheimildir sem tengdust verkefni: „Nemendur hefjast handa við að lesa. Alger ró í stofunni.“ Einnig var lestur upphátt tengdur tungumálanámi, eins og í einni kennslustund í pýsku par sem nemendur lásu upphátt úr kennslubókinni fyrir bekkinn: „Nemandi les. Aðrir fylgjast með.“

Að meðaltali birtust fimm athafnir í kennslustund, en algengast var að fjórar athafnir kæmu fyrir í einni kennslustund (sjá Mynd 1). Dað kom aðeins fyrir prisvar sinnum að níu virkniathafnir birtust saman í kennslustundum, en pað var hæsta tíðni athafna og sýnir mikinn fjölbreytileika í pví hvernig pátttaka nemenda birtist. Lægsta tíðni athafna var tvær athafnir sem birtist í fjórum kennslustundum.

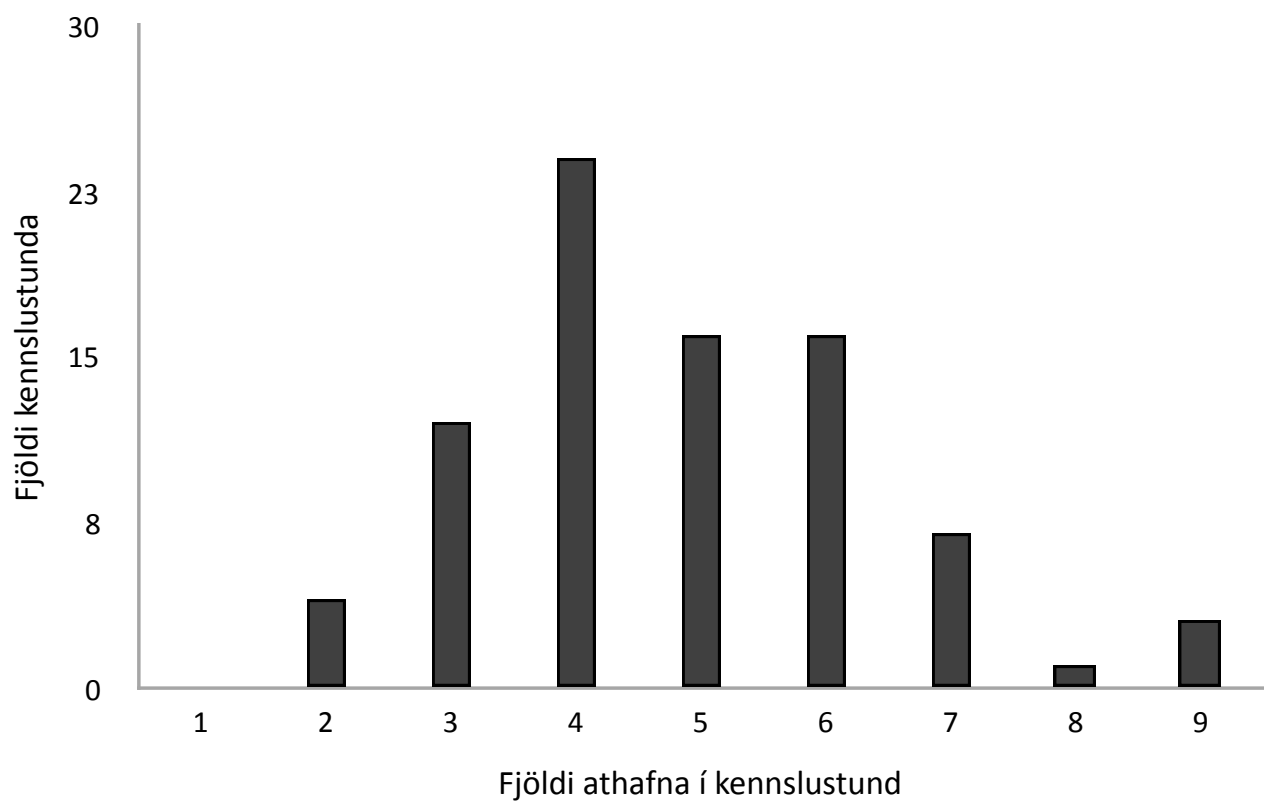

Mynd 1. Myndin sýnir tíðni pátttökustunda eftir tíðni athafna. Athöfn var aðeins talin einu sinni í hverri kennslustund og sýnir myndin pví fjölbreytileika athafna í kennslustundunum. 
Fylgni á milli athafna var skoðuð með phi-stuðlinum og var almennt lítil (á bilinu 0 til +/- 0.3) og einungis fannst marktæk fylgni í peim premur tilvikum par sem fylgnin var mest. Jákvæð fylgni var á milli pess að lesa (í hljóði eða upphátt) og svara spurningum kennara $(0.30 ; p<0,05)$, sem gefur til kynna að pessar aðferðir séu gjarnan notaðar saman, til dæmis par sem nemendur vinna með hliðsjón af tilteknum textum. Einnig var jákvæð fylgni á milli pess að hjálpast að og biðja um aðstoð kennara $(0.27 ; p<0,05)$ sem gæeti gefið til kynna að pegar nemendur purfa aðstoð við vinnu pá séu peir líklegir til að biðja bæði kennara og samnemendur um aðstoð, frekar en að spyrja kennara spurninga yfir allan hópinn. Neikvæð fylgni var á milli pess að ræða um viðfangsefnið og biðja um aðstoð kennara $(-0.27 ; p<0,05)$ og fóru pví pessar athafnir sjaldan saman sem gæti bent til pess að nemendur teldu sig ekki purfa aðstoð kennara við umræður.

\section{Kennsluaðferðir}

Kennslustundir voru flokkaðar eftir pví hvort pær kennsluaðferðir sem beitt var meirihluta stundarinnar voru taldar kennarastýrðar eða nemendamiðaðar (sjá Töflu 2). Ápekkur fjöldi kennslustunda flokkaðist í pessa tvo flokka en færri í flokk blandaðra aðferða. Баð er áhugavert að í flestum kennslustundum voru annaðhvort kennarastýrðar eða nemendamiðaðar kennsluaðferðir í meirihluta. Hér á eftir verður áherslan fyrst og fremst að bera saman kennslustundir sem flokkuðust sem annaðhvort kennarastýrðar eða nemendamiðaðar.

Athafnir nemenda sem greindar voru skiptust nokkuð jafnt á milli kennslustunda sem flokkuðust sem nemendamiðaðar og kennarastýrðar. Að meðaltali voru örlítið fleiri athafnir greindar í nemendamiðuðum kennslustundum (sjá Töflu 2) en hinum tveimur flokkunum, en sá munur var ekki marktækur $(\mathrm{p}>0,05)$.

Tafla 2. Flokkun pátttökustunda eftir kennsluaðferðum sem beitt var í meirihluta kennslustundarinnar.

\begin{tabular}{lccc}
\hline Flokkun kennslustunda & $\begin{array}{c}\text { Tíðni (hlutfall) } \\
\text { kennslustunda }\end{array}$ & $\begin{array}{c}\text { Tíðni (hlutfall) } \\
\text { athafna }\end{array}$ & $\begin{array}{c}\text { Meðaltal (sf) athafna } \\
\text { i kennslustund }\end{array}$ \\
\hline Kennarastýrðar aðferðir í meirihluta & $38(46 \%)$ & $179(45 \%)$ & $4,7(1,4)$ \\
Nemendamiðaðar aðferðir í meirihluta & $34(41 \%)$ & $171(43 \%)$ & $5,0(1,7)$ \\
Blandaðar aðferðir & $11(13 \%)$ & $50(12 \%)$ & $4,5(1,9)$ \\
\hline Samtals & $83(100 \%)$ & $400(100 \%)$ & $4,8(1,6)$ \\
\hline
\end{tabular}

Í meirihluta kennarastýrðra kennslustunda (32 af 38) komu fyrirlestrar eða töflukennsla fyrir. Sem dæmi má taka kennslustund í stærðfræði par sem töflukennsla fór fram, en kennarinn skrifaði dæmi og útskýrði samtímis alla kennslustundina:

Nemendur skrifa upp eftir kennaranum. Spyrja ekki frekar og virðast nota tímann til að skrifa allt upp eftir kennaranum. Allir skrifa glósur í bók, enginn með tölvu á borðinu. (Úr dálknum par sem athöfnum nemenda er lýst)

Einnig var algengt að eftir innlegg frá kennara ynnu nemendur einstaklingsverkefni í verkefnabókum, en kennarinn gekk á milli og aðstoðaði. Til dæmis í kennslustund í efnafræði:

Nemendur hlustuðu á kennarann og byrjuðu fljótlega að vinna verkefni sem kennarinn útbjó fyrir nemendur. Nemendur leysa verkefnin í eigin hefti. (Úr dálknum par sem athöfnum nemenda er lýst)

Í kennarastýrðum kennslustundum stýrði kennarinn ferðinni, en nemendur fylgdust með og fóru eftir fyrirmælum. Í nemendamiðuðum kennslustundum réðu nemendur aftur á móti frekar hvernig kennslustundin próaðist, fengu sjálfir oft að ráđa pví hvernig peir öfluðu sér pekkingar eða hvernig peir skiluðu henni frá sér. Í kennslustundum sem flokkuðust sem nemendamiðaðar var gjarnan notast við leitaraðferðir, sjálfstæð eða skapandi verkefni og hópvinnuverkefni. Eitt dæmi um nemendamiðaða kennslustund var í dönsku par sem nemendur skiptu sér í hópa. Verkefnafyrirlögn var lýst á pennan hátt: 
Nemendur ákveða sjálfir hvernig peir skila verkefninu endanlega (til dæmis munnlega, skriflega, glærur, bæklingur, ferðamöguleikar o.s.frv.). Nemendur eru hvattir til að nota hugmyndaflugið. Dau [pað er nemendur] eiga að nýta a.m.k. 3-4 heimildir á dönsku. Degar skilað er á hver og einn í hópnum að hafa skrifað a.m.k. hálfa síðu á dönsku. Kennari fær texta hvers og eins í hendur áđur en hópurinn sameinar textana í eina heild. Nemendur eru hvattir til að hjálpast að. (Úr dálknum par sem athöfnum kennara er lýst)

Darna er kennarinn búinn að setja tiltekinn ramma fyrir verkefnið en nemendur stýra útfærslu. Dæmigert var í nemendamiðuðum kennslustundum að kennarinn leiðbeindi og aðstoðaði við vinnu en stýrði henni ekki. Kennarinn setti pannig gjarnan ábyrgð á nemendur; peir purftu að velja sér viðfangsefni, ákveða aðferðir og úrvinnslu.

Í flokknum blandaðar kennsluaðferðir flokkuðust kennslustundir pegar ekki náðist viðmið um að kennarastýrðar eða nemendamiðaðar aðferðir væru notaðar í 80\% af kennslustund. Í pessum kennslustundum hófst stundin gjarnan á fyrirlestri en í síðari hlutanum var farið í hópavinnu, prautalausnir eða lausnarleitarverkefni. Dæmi má nefna úr kennslustund í stærðfræði, par sem kennarinn byrjaði tímann á töflukennslu par sem hann reiknaði dæmi, en nemendur fylgdust með. Seinni hluti tímans fór hins vegar í að nemendur áttu að para sig saman í hópa og leysa verkefni:

Verkefnið er að búa til öskju með pví að klippa horn úr blaði. Kennarinn brýtur blað á borðinu og sýnir öskju. Askjan á að hafa eins mikið rúmmál og mögulegt er. Nemendur eiga sjálfir að finna út hvernig eigi að hanna pessa öskju svo hún hafi eins mikið rúmmál og hægt er. (Úr dálknum par sem athöfnum kennara er lýst)

Pegar einstakar athafnir nemenda sem greindar voru eru skoðaðar í kennarastýrðum kennslustundum annars vegar og nemendamiðuðum hins vegar kemur í ljós að aðeins prjár virkniathafnir af ellefu voru algengari í kennarastýrðum kennslustundum: Að sýna athygli (hlusta og fylgjast með), að svara spurningum kennara um námsefnið og skrifa eða glósa (sjá Töflu 3). Aðeins athöfnin að sýna athygli $\mathrm{t}(70)=-2,96, p<0,05,95 \%$ öryggismörk $[-0,56,-0,11]$ var marktækt oftar að finna í kennarastýrðum kennslustundum. Aðrar athafnir voru algengari í nemendamiðuðum kennslustundum, en aðeins athafnirnar að leita og nota efnivið $(\mathrm{t}(70)=2,99, p<0,05$, $95 \%$ öryggismörk $[0,91,0,46])$ og að hjálpast að við að leysa verkefni $(\mathrm{t}(70)=2,96, p<0,05,95 \%$ öryggismörk $[0,11,0,56])$ komu marktækt oftar fram.

Tafla 3. Tíðni athafna og hlutfall af kennarastýrðum og nemendamiðuðum kennslustundum.

\begin{tabular}{lcc}
\hline $\begin{array}{l}\text { Athafnir nemenda (birtingarmynd p } \\
\text { átttöku) }\end{array}$ & $\begin{array}{c}\text { Tíóni (\%) í kennarastýrò- } \\
\text { um kennslustundum }\end{array}$ & $\begin{array}{c}\text { Tíðni (\%) í nemenda- } \\
\text { miðuðum kennslustundum }\end{array}$ \\
\hline Vinna verkefni & $30(79 \%)$ & $29(85 \%)$ \\
Spyrja kennara spurninga um námsefnið & $30(79 \%)$ & $27(79 \%)$ \\
Sýna athygli (hlusta, fylgjast með)* & $25(66 \%)$ & $11(32 \%)$ \\
Ræða um viðfangsefnið (sín á milli eða við & $17(45 \%)$ & $21(62 \%)$ \\
kennara) & $13(34 \%)$ & $23(68 \%)$ \\
Hjálpast að* & $21(55 \%)$ & $11(32 \%)$ \\
Svara spurningum kennara & $18(47 \%)$ & $16(47 \%)$ \\
Biðja um aðstoð kennara & $12(32 \%)$ & $5(15 \%)$ \\
Skrifa (glósa) & $6(16 \%)$ & $11(32 \%)$ \\
Sýna áhuga á ýmsa vegu & $3(8 \%)$ & $12(35 \%)$ \\
Leita og nota efnivið (t.d. heimildaleit)* & $4(11 \%)$ & $5(15 \%)$ \\
Lesa (í hljóði eða upphátt) & $179(100 \%)$ & $171(100 \%)$ \\
Samtals & &
\end{tabular}

* Marktækur munur á milli kennarastýrðra og nemendamiðaðra kennslustunda miðað við $p<0,05$. 
Dessar niðurstöður gefa til kynna að pátttaka nemenda í kennslustundum virðist ekki tengjast tilteknum kennsluaðferðum, par sem pátttökustundirnar skiptust frekar jafnt í nemendamiðaðar og kennarastýrðar kennslustundir. Pannig koma ákveðnar birtingarmyndir pátttöku nemenda tiltölulega jafnt fyrir í bæði kennarastýrðum og nemendamiðuðum kennslustundum, til dæmis að vinna verkefni, spyrja kennara spurninga um námsefnið, biðja um aðstoð kennara og lesa. Đó voru tilteknar athafnir sem komu oftar fyrir í annars vegar nemendamiðuðum kennslustundum (leita og nota efnið og hjálpast að) og hins vegar kennarastýrðum (sýna athygli), enda tengjast pessar athafnir pví hvernig pessir ólíku kennsluaðferðaflokkar eru skilgreindir.

\section{Viðmót og athafnir kennara}

Viðmót og athafnir kennara í pátttökustundunum voru skoðaðar og við greiningu komu fram fjögur pemu: Jákvætt viðmót, hlýlegt andrúmsloft sem kennari átti pátt í að skapa, skýr fyrirmæli kennara og hvetjandi kennari. Hvert pema var aðeins skráð einu sinni fyrir hverja kennslustund prátt fyrir að hegðun eða lýsing á viðmóti sem félli par undir kæmi oftar fyrir.

Jákvætt viðmót kennara birtist oftast í pví að kennari tók vel á móti nemendum pegar peir komu inn í kennslustundina, ávarpaði pá með nafni, fylgdist með hvar nemendur voru staddir í námsefninu og var reiðubúinn til að aðstoða pá, ásamt að nota uppbyggjandi og jákvæða samskiptahætti. Til dæmis kemur fram í athugasemdum rannsakenda í lýsingu á kennslustund í myndvinnslu:

Kennari er vinsamlegur við nemendur pegar hann gengur á milli og aðstoðar, gefur sér góðan tíma með hverjum og einum. Kennari ávarpar alla nemendur með nafni og virkar mjög hjálplegur við að aðstoða og leiðbeina.

Einnig kom fram að kennarinn bauð öllum góðan daginn og heilsaði nemendum sem komu seint. Eins fylgdist kennarinn grannt með stöðu nemenda: „Kennari gengur á milli og spyr hvernig gangi með verkefnin“" (úr lýsingu á framvindu kennslustundar). Darna gefa athafnir kennara til kynna jákvætt viðmót gagnvart nemendum og að honum sé umhugað um hvernig peim gangi. Tekið saman má segja að pemað jákvætt viðmót lýsi beinum aðgerðum kennara til að stýra stundinni, aðgerðum sem pó tengjast ekki beint námsefninu.

Að skapa hlýlegt andrúmsloft í kennslustund birtist yfirleitt með peim hætti að kennarinn sá til pess að í kennslustofunni væri vinnufriður, par sem allir höfðu tækifæri til að vinna í ró og næði. Kennari mætti nemendum gjarnan á jafningjagrundvelli og samskipti nemenda og kennara voru góð. Kennslustundum í pessum flokki var iðulega lýst eins og einni stund í efnafræði: „Баð ríkti notalegur vinnuandi í stofunni allan tímann“ (úr lýsingu rannsakenda á kennslustundinni 1 hnotskurn). Tekið saman pá einkenndist pemað hlýlegt andrúmsloft af beinum sem óbeinum aðgerðum sem voru til pess fallnar að skapa vinnufrið og vellíðan.

Demað skýr fyrirmæli birtist meðal annars í pví að kennari hafði skýrt upphaf og endi á kennslustundinni, hann fór yfir hvað fram undan væri í kennslustundinni eða rifjaði upp kennsluefni í síðasta tíma til að geta byggt ofan á fyrri pekkingu. Eins voru pað talin skýr fyrirmæli pegar kennari athugaði reglulega hvort nemendur fylgdu sér eftir til að vera viss um að allir skildu efnið. Detta átti við um kennslustund í íslensku par sem „kennari fjallar um efni síðasta tíma með nemendum“ áður en hann lagði verkefni tímans fyrir og „,bendir nemendum á að petta vilji hann að pau læri/muni/kunni“" (úr lýsingum á framvindu kennslustunda). Í framhaldi skrifaði hann upplýsingarnar á töfluna svo nemendur hefðu pær fyrir framan sig við vinnuna. Demað skýr fyrirmæli byggist á beinum aðgerðum, eins og pemað jákvætt viðmót, en sker sig úr að bví leyti að pær eru kennslufræðilegs eðlis og fyrirfram skipulagðar í beinum tengslum við námsefnið.

Demað hvetjandi kennari kom oftast fram með pví að kennari hrósaði nemendum, var jákvæður í endurgjöf til peirra eða gerði til peirra kröfur. Eins má nefna pegar kennari sýndi fram á tilgang með náminu. Dæmi um hvetjandi kennara má sjá í kennslustund í pýsku: „[Kennarinn] gengur á 
milli og stoppar við ákveðin pör og aðstoðar og hrósar.“ Í lýsingu er til dæmis haft eftir honum „flottur texti hjá ykkur“ eða „vel gert“ (úr lýsingum á framvindu kennslustunda). Parna notaði kennari hvatningu til að virkja nemendur og halda peim við efnið. Бemað hvetjandi kennari er til marks um beinar aðgerðir til að stuðla að námi í kennslustundinni og verklaginu beitt eftir pörfum frekar en fyrir fram ákveðnu skipulagi.

Rétt er að undirstrika að sundurgreiningin í fjögur pemu var ekki gerð til pess að skapa fullkomlega eðlisólík atriði heldur til pess að koma betur auga á hvað pað væri í viðmóti og athöfnum kennara sem gæti skýrt pátttöku nemenda í kennslustundunum. Í textanum hér að ofan og í Töflu 4 má pó sjá að afmörkunin á sér forsendur í pví til hvers og hvernig kennari beitir ákveðnum aðgerðum, sumum beint tengdum námsefninu hverju sinni en öðrum talsvert almennari.

Tafla 4. Viðmót og athafnir kennara.

\begin{tabular}{|c|c|c|}
\hline $\begin{array}{l}\text { Dema úr viðmóti og } \\
\text { athöfnum }\end{array}$ & Lýsing & Dæmi úr vettvangslýsingum \\
\hline Jákvact viðmót: & Tók vel á móti nemendum. & „Kennarinn býður góðan daginn.“ \\
\hline \multirow{4}{*}{$\begin{array}{l}\text { Aðgerðir til að stýra } \\
\text { stundinni, eftir pörfum, } \\
\text { ekki endilega tengdar } \\
\text { námsefninu. }\end{array}$} & & \multirow{2}{*}{$\begin{array}{l}\text { „Kennari gengur á milli og aðstoðar } \\
\text { nemendur.“ }\end{array}$} \\
\hline & Ávarpaði nemendur með nafni. & \\
\hline & \multirow[t]{2}{*}{$\begin{array}{l}\text { Notaði uppbyggilega } \\
\text { samskiptahætti. }\end{array}$} & $\begin{array}{l}\text { „Kíkti á vinnu nemenda og svaraði } \\
\text { spurningum.“ }\end{array}$ \\
\hline & & $\begin{array}{l}\text { „Gefur sér góðan tíma með } \\
\text { hverjum og einum.“" }\end{array}$ \\
\hline Hlýlegt andrúmsloft: & Sjálfur jákvæður. & „Рað ríkti notalegur vinnuandi í \\
\hline \multirow{3}{*}{$\begin{array}{l}\text { Beinar sem óbeinar } \\
\text { aðgerðir, til pess fallnar } \\
\text { að skapa vinnufrið og } \\
\text { vellíðan. }\end{array}$} & Samskipti nemenda og & \multirow{3}{*}{$\begin{array}{l}\text { „Létt andrúmsloft og samskipti } \\
\text { nemenda og kennara virtust gód.“ }\end{array}$} \\
\hline & kennara góð. & \\
\hline & $\begin{array}{l}\text { Mretti nemendum á } \\
\text { jafningjagrundvelli. }\end{array}$ & \\
\hline \multirow{4}{*}{$\begin{array}{l}\text { Skýr fyrirmœli: } \\
\text { Beinar kennslufræði- } \\
\text { legar aðgerðir nátengdar } \\
\text { námsefninu, fyrir fram } \\
\text { skipulagðar. }\end{array}$} & $\begin{array}{l}\text { Spurði reglulega hvort } \\
\text { nemendur fylgdu sér eftir. }\end{array}$ & \multirow{2}{*}{$\begin{array}{l}\text { „Kennari fjallar um efni síðasta } \\
\text { tíma með nemendum.“ } \\
\text { „Kennari skrifar á töfluna } \\
\text { upplýsingar til útskýringar.“ }\end{array}$} \\
\hline & $\begin{array}{l}\text { Rifjaði upp síðustu } \\
\text { kennslustund. }\end{array}$ & \\
\hline & $\begin{array}{l}\text { Hafði skýrt upphaf og endi } \\
\text { á kennslustundinni og } \\
\text { útskýrði næstu skref } \\
\text { kennslustundarinnar. }\end{array}$ & \multirow[t]{2}{*}{$\begin{array}{l}\text { „Verkefnið var skýrt, verkefnablaði } \\
\text { var dreift til nemenda og munnleg } \\
\text { lýsing kennarans einnig skýr.“" }\end{array}$} \\
\hline & $\begin{array}{l}\text { Gott samspil skriflegra lýsinga } \\
\text { og munnlegra útskýringa á } \\
\text { verkefnum. }\end{array}$ & \\
\hline Hvetjandi kennari: & Veitti jákvæða endurgjöf. & $\begin{array}{l}\text { „Hrósar peim, segir að petta gangi } \\
\text { vel hjá peim.“ }\end{array}$ \\
\hline \multirow[t]{4}{*}{$\begin{array}{l}\text { Beinar aðgerðir til að } \\
\text { stuðla að námi, eftir } \\
\text { pörfum. }\end{array}$} & $\begin{array}{l}\text { Sýndi nemendum að hann } \\
\text { hefði til peirra miklar } \\
\text { væntingar. }\end{array}$ & $\begin{array}{l}\text { „Hann gengur á milli og stoppar } \\
\text { við ákveðin pör og aðstoðar og } \\
\text { hrósar.“ }\end{array}$ \\
\hline & $\begin{array}{l}\text { Náđi að gera námsefnið } \\
\text { áhugavert. }\end{array}$ & \multirow{3}{*}{$\begin{array}{l}\text { „Kennari var hvetjandi, pekkti } \\
\text { nemendur vel, náði vel til peirra } \\
\text { og hafði góða yfirsýn.“" }\end{array}$} \\
\hline & Útskýrði tilgang námsefnisins. & \\
\hline & $\begin{array}{l}\text { Hafði yfirsýn um hvað } \\
\text { gerðist í kennslustofunni. }\end{array}$ & \\
\hline
\end{tabular}


Algengast var að öll fjögur pemun kæmu fram í einni kennslustund, eða í 35 (42\%) kennslustundanna. Sjaldnast var aðeins eitt pema skráð á kennslustund, eða í sjö (8\%) kennslustundum. Tvö pemu komu fram í 28\% pátttökustunda og prjú í 19\% peirra. Í Töflu 5 má sjá að pemað jákvætt viðmót kennara kom oftast fram, en hvetjandi kennari sjaldnast. Dó kom pað pema fram í um tveimur priðju kennslustunda og pví var mjög algengt að pemun kæmu fram í kennslustundunum. Einnig sýndu niðurstöður að almennt komu pemun nokkuð jafnt fyrir í kennarastýrðum og nemendamiðuðum kennslustundum, fyrir utan að pemað hvetjandi kennari kom marktækt oftar fyrir í nemendamiðuðum kennslustundum en kennarastýrðum, t(70) $=4,16, p<0,001,95 \%$ öryggismörk [0,22, 0,64].

Tafla 5. Fjöldi skipta (og hlutfall af heildarfjölda kennslustunda í úrtakinu $n=83$ ) par sem pemun um viðmót og athafnir kennara komu fyrir í kennslustundunum. Sömu upplýsingar eru einnig gefnar fyrir kennslustundir sem annars vegar voru flokkaðar sem nemendamiðaðar (n =34) og hins vegar sem kennarastýrðar $(\mathrm{n}=38)$.

\begin{tabular}{lccc}
\hline $\begin{array}{l}\text { Flokkun viðmóts og athafna } \\
\text { kennara }\end{array}$ & $\begin{array}{c}\text { Tíoni (\%) í kennslu- } \\
\text { stundum }\end{array}$ & $\begin{array}{c}\text { Tíðni (\%) í nem- } \\
\text { endamiðuðum } \\
\text { kennslustundum }\end{array}$ & $\begin{array}{c}\text { Tíðni (\%) í } \\
\text { kennarastýrðum } \\
\text { kennslustundum }\end{array}$ \\
\hline Jákvætt viðmót & $72(87 \%)$ & $29(85 \%)$ & $34(89 \%)$ \\
Hlýlegt andrúmsloft & $61(73 \%)$ & $29(85 \%)$ & $27(71 \%)$ \\
Skýr fyrirmæli & $59(71 \%)$ & $25(74 \%)$ & $24(63 \%)$ \\
Hvetjandi kennari & $51(61 \%)$ & $27(79 \%)$ & $16(42 \%)$
\end{tabular}

Marktæk jákvæð fylgni var á milli pess að kennari væri með jákvætt viðmót og pess að skapa hlýlegt andrúmsloft annars vegar $(0,44 ; p<0,001)$ og setja skýr fyrirmæli hins vegar $(0,31 ; p<$ 0,05). Jákvæð lítil fylgni $(0,12-0,18)$ var á milli annarra pema en hún reyndist ekki marktæk. Detta gefur til kynna að töluverður hluti pátttökustundanna hafi einkennst af pví að kennari sé með jákvætt viðmót og pá annaðhvort skapi einnig hlýlegt andrúmsloft eða setji skýr fyrirmæli.

\section{Umræður}

Markmið rannsóknarinnar var að varpa ljósi á pað sem einkennir kennslustundir í framhaldsskólum á Íslandi par sem nemendur taka pátt í pví sem kennari ætlast til. Í fyrsta lagi var ætlunin að greina hvernig pátttaka nemenda birtist í kennslustundum, í öðru lagi að athuga hvort kennarar beittu frekar kennarastýrðum eða nemendamiðuðum kennsluaðferðum í pessum kennslustundum og í priðja lagi skoða hvað einkenndi viðmót og athafnir kennara í kennslustundum.

\section{Birtingarmyndir pátttöku nemenda og tengsl við kennsluaðferðir}

Dátttaka nemenda í kennslustundum birtist í pessari rannsókn einna skýrast í gegnum að nemendur unnu verkefni og spurðu kennara spurninga um námsefnið. Fjölbreytileiki verkefna var mikill - allt frá pví að vinna opin verkefni par sem nemendur unnu saman að pví að finna lausn að einstaklingsverkefnum með einni skilgreindri niðurstöðu. Algengustu birtingarmyndir pátttöku nemenda voru pví að gera eitthvað frekar en að vera aðgerðarlausir (sbr. Corrodi o.fl., 2019). Раð аð sýna athygli var pó priðja algengasta birtingarmyndin og kom fyrir í um helmingi stundanna. Að meðaltali komu fram fimm athafnir í hverri kennslustund en minnst tvær og mest níu. Á heildina virðist pátttaka nemenda birtast með nokkuð fjölbreyttum hætti. Dví má segja að námshegðun nemenda í pessum kennslustundum hafi sýnt fram á nokkuð fjölbreytta pátttöku og námslega skuldbindingu nemenda (Greenwood o.fl., 2002; Spanjers o.fl., 2008).

Fylgni á milli athafna var almennt lítil en marktæk fylgni mældist í premur tilvikum par sem fylgnin var mest. Athafnirnar að lesa og svara spurningum fóru saman, og eins athafnirnar að hjálpast að og biðja um aðstoð kennara. Í pessum tilvikum má ætla að pessar athafnir tengist 
tilteknum námsgreinum eða kennsluaðferðum - í fyrra tilvikinu eiga nemendur að kunna skil á tilteknu námsefni og í pví síðara eiga peir að leysa verkefni sem tekur pá tíma að skilja eða ljúka. Athafnirnar að ræða um viðfangsefnið og biðja um aðstoð kennara fóru aftur á móti sjaldan saman og bendir pað til pess að í umræðum hafi vinnan verið með peim hætti að síður purfti aðstoð kennara.

Hvort kennarar beittu nemendamiðuðum eða kennarastýrðum kennsluaðferðum virtist ekki ráda miklu um hvort nemendur tækju pátt í kennslustundinni par sem nokkuð jafn fjöldi pátttökustundanna einkenndist að mestu leyti af kennarastýrðum kennsluaðferðum annars vegar og nemendamiðuðum hins vegar. Rannsóknir hafa sýnt að kennarar beiti oft frekar kennarastýrðum kennsluaðferðum og eins segja nemendur að kennarar noti mikið töflukennslu og láti nemendur vinna sjálfa í vinnu- eða verkefnabókum (Fisher, 2009; Gerður G. Óskarsdóttir, 2014; Juuti o.fl., 2010; Pianta o.fl., 2007; Svanhildur Kr. Sverrisdóttir o.fl., 2011). Niðurstöður pessarar rannsóknar samræmast pessu að hluta en sýna pó einnig að verkefni geta verið mjög fjölbreytt.

Раð kom á óvart að athafnir sem sýndu pátttöku nemenda komu nokkuð jafnt fram í bæði kennarastýrðum og nemendamiðuðum kennslustundum í pessari rannsókn. Töluvert hefur verið rætt um kosti nemendamiðaðra kennsluaðferða til að hvetja til virkni nemenda og pá sérstaklega fjölbreyttari virkni nemenda (Bolinger og Warren, 2007; Braičić o.fl., 2014; Juuti o.fl., 2010; Schmidt o.fl., 2018; Taylor og Parsons, 2011). Hér kom pað ekki eins skýrt fram og virtust athafnir sem kölluðu á pátttöku nemenda koma nokkuð jafnt fram í báðum flokkum. Degar birtingarmyndir pátttöku eru skoðaðar í samhengi við kennsluaðferðir virtust flestar athafnir koma jafnt fram í kennarastýrðum og nemendamiðuðum kennslustundum. Undantekning frá pessu var athöfnin að sýna athygli (hlusta og fylgjast með) sem var algengari í kennarastýrðum kennslustundum og eins voru athafnirnar að leita og nota efnivið og að hjálpast að við að leysa verkefni algengari í nemendamiðuðum kennslustundum. Pátttaka nemenda í kennslustund virðist samkvæmt pessum niðurstöðum ekki háð pví að kennarar beiti nemendamiðuðum frekar en kennarastýrðum kennsluaðferðum. மó er mikilvægt að nefna að kennarar geta haft ólíkar skoðanir á pví hvað teljist eftirsóknarverð pátttaka og telja peir pá ekki allar athafnir jafngildar. Ef kennara finnst til dæmis eftirsóknarvert að fá nemendur til að taka pátt í vinnunni með pví að leita og nota efnivið benda pessar niðurstöður til pess að hann ætti frekar að nota nemendamiðaðar kennsluaðferðir.

\section{Viðmót og athafnir kennara}

Fjögur pemu komu fram pegar viðmót og athafnir kennara voru greind í pátttökustundunum: Jákvæett viðmót, hlýlegt andrúmsloft, skýr fyrirmæli og hvetjandi kennari. Demun komu öll oft fram; hvert og eitt peirra birtist í minnst helmingi stundanna og algengt var að öll fjögur kæmu fram í kennslustund. Dví má segja að pessi fjögur pemu hafi almennt einkennt viðmót og athafnir kennara í kennslustundunum. Hér má kannski finna eina skýringu á pátttöku nemenda. Rannsóknir hafa sýnt að viðmót kennara hefur mikið að segja um námshegðun nemenda. Samskipti kennara og nemenda sem einkennast af góðri framkomu og virðingu auka skuldbindingu nemenda til náms og sömuleiðis sú upplifun nemenda að gengi peirra í náminu og viðvera í kennslustundum skipti kennara máli (Kristjana Stella Blöndal og Sigrún Aðalbjarnardóttir, 2016; Li og Lerner, 2011; Murdock, 1999; Roorda o.fl., 2011; Rosenfeld o.fl., 2000; Voelkl og Frone, 2000). Dessar niðurstöður gefa tilefni til að ætla að nemendur, sem fundu reglulega fyrir jákvæðu viðmóti og hvatningu frá kennara sínum, hafi upplifað meiri skuldbindingu til náms og pví tekið pátt í pví sem kennari ætlaðist til.

Á heildina litið komu pemun fjögur nokkuð jafnt fram í kennslustundum sem flokkuðust sem kennarastýrðar og nemendamiðaðar. Demað jákvæett viðmót kom oftar fram í kennarastýrðum stundum og pemun hvetjandi kennari og hlýlegt andrúmsloft komu oftar fram í nemendamiðuðum kennslustundum. Einkum virtust peir kennarar sem beittu nemendamiðuðum kennsluaðferðum frekar hvetja nemendur en peir sem beittu kennarastýrðum aðferðum. Má ætla að hvatn- 
ing kennara sé liður í að beita nemendamiðuðum aðferðum, sérstaklega par sem skapandi og opin verkefni geta verið mjög krefjandi fyrir nemendur en jafnframt virðast pær aðgerðir sem fólu í sér jákvætt viðmót, svo sem að taka vel á móti nemendum og ávarpa pá með nafni, stuðla að pátttöku í kennarastýrðu starfi.

Áhugavert er að marktæk fylgni fannst á milli pess að kennarar voru með jákvætt viðmót og sköpuðu hlýlegt andrúmsloft 1 kennslustundinni annars vegar og settu skýr fyrirmæli hins vegar. Dessar niðurstöður gefa til kynna að petta einkenni stóran hluta pátttökustundanna, og má leiða líkur að pví að pegar kennarar gæeti að pessu fái peir nemendur til að taka pátt í pví sem gert er í kennslustundinni.

\section{Takmarkanir og framhald rannsókna}

Mikilvægt er að hafa í huga takmarkanir rannsóknarinnar. Ekki síst á petta við um greininguna á viðmóti og athöfnum kennara, pví að eins og áður hefur komið fram, pá var gögnum ekki safnað með pað fyrir augum að greina viðmót og athafnir kennara á pann hátt sem hér var gert. Áhugavert væri að rannsaka petta frekar og pá skrá framvindu kennslustunda með hliðsjón af pessum fjórum pemum sem hér komu fram.

Dá var ekki mögulegt að bera saman pátttökustundirnar og pær kennslustundir sem ekki náðu viðmiðum um pátttöku par sem stundir sem náðu örugglega ekki viðmiðum voru einfaldlega of fáar til samanburðar. Á sama hátt er vitanlega ekki unnt að fullyrða að pessar niðurstöður gildi um allar kennslustundir í framhaldsskólum. Að sama skapi er heldur ekkert sem bendir til pess að kennslustundirnar 130, sem valið var úr (sjá Ingvar Sigurgeirsson o.fl., 2018) eða kennslustundirnar 83, sem greindar voru, skeri sig úr á neinn sérstakan hátt.

Eins er mikilvægt að hafa í huga að sú nálgun sem hér er höfð til að skoða námslega skuldbindingu nemenda í kennslustundum vísar einungis til hegðunar nemenda sem bendir til pátttöku í pví sem ætlast er til af kennara. Ekki er hægt að fullyrða neitt um innri áhuga nemenda, hversu djúpt peir hugsa um eða tileinka sér efnið, eða hvort peir hafa gaman af bví sem peir eru að fást við (Schmidt o.fl., 2018). Dannig verður kennarinn og hlutverk hans í að fá nemendur til að taka pátt í forgrunni, en nemandi meira í hlutverki viðtakanda. Dessa nálgun má gagnrýna fyrir pær sakir að ábyrgð nemenda á eigin námi er ekki tekin með í reikninginn og skuldbinding pannig ekki skilin sem sjálfviljug pátttaka nemenda vegna innri áhuga eða trúar gildi peirrar pekkingar sem um ræðir (Sheppard, 2011).

Rétt er að fram komi að pessi greining á pátttöku fól ekki í sér að leggja mat á gæði kennslustundanna, enda pótt að jafnaði verði að telja að sé æskilegt og gott að nemendur taki pátt í pví sem lagt var upp með. Greiningin sýnir pó að ef kennari sækist eftir virkri pátttöku nemenda er mikilvægt að geta notað fjölbreyttar kennsluaðferðir til að ná til sem flestra nemenda. Eins er mikilvægt að hafa í huga hve pátttaka nemenda getur komið fram á ólíka vegu.

\section{Lokaorð}

Niðurstöðurnar benda til pess að pegar pátttaka nemenda í kennslustund er skoðuð, og par með námsleg skuldbinding peirra eins og hún er skilgreind hér, er ekki aðalatriðið hvort kennari beiti kennarastýrðum eða nemendamiðuðum kennsluaðferðum. Degar kennslustundir par sem nemendur tóku virkan pátt í pví sem kennarinn ætlaðist til voru skoðaðar virtust pær helst eiga pað sameiginlegt að kennarar sýndu jákvætt viðmót, sköpuðu hlýlegt andrúmsloft og gáfu skýr fyrirmæli. Par sem nemendamiðuðum kennsluaðferðum var beitt virtust kennarar sem fengu nemendur til pátttöku sérstaklega vera hvetjandi.

Telja má að pessar niðurstöður geti verið til leiðsagnar við nemendur í kennaranámi og kennara á vettvangi, til dæmis með pví að vekja athygli á mikilvægi viðmóts kennara, gefa skýr fyrirmæli 
og hugleiða hvernig hægt er að skapa góðan vinnufrið í kennslustund. Detta eru vissulega fremur einföld sannindi - en niðurstöðurnar um viðmót og athafnir eru hins vegar í samræmi við faglega orðræðu í kennslufræði. [2]

\section{Aftanmálsgreinar}

1. Megingagnasöfnun í rannsókninni Starfshættir í framhaldsskólum fór fram á tímabilinu október 2013 til nóvember 2014 í níu framhaldsskólum, auk pess sem rannsóknartækin voru forprófuð í tíunda skólanum. Gögnin eru vettvangslýsingar á 130 kennslustundum og yfir 60 afrituð viðtöl sem voru tekin við nemendur (hópviðtöl), kennara og stjórnendur. Um er að ræða ljósmyndir úr kennslustofum, kennsluáætlanir og önnur skrifleg gögn. Fimmtán manna hópur fræðafólks við Menntavísinda- og Félagsvísindasvið Háskóla Íslands tók pátt í gagnasöfnuninni. Rannsóknin naut styrkja úr Rannsóknasjódi Háskóla Íslands á árunum 2013-2015og frá Norræna öndvegissetrinu Justice Through Education in the Nordic Countries, sem styrkt var af NordForsk, 2013-2018. Við pökkum sérstaklega framhaldsskólunum sem veittu aðgang að starfinu í rannsóknarskyni.

2. Greinin er byggð á meistaraprófsverkefni Hafrúnar Hafliðadóttur í menntun framhaldsskólakennara, sálfræðikennslu sem ber heitið Virkni nemenda í kennslustundum í framhaldsskólum á Íslandi og var unnin í samstarfi við Elsu Eiríksdóttur og Ingólf Ásgeir Jóhannesson.

\section{Student classroom engagement in Icelandic upper secondary schools}

This article outlines a study on how Icelandic upper secondary school students engage in classroom work (academic engagement) through classroom participation (Greenwood, Horton, and Utley, 2002; Schmidt, Rosenberg, and Beymer, 2018). The objective is threefold: Firstly, to analyze how student participation manifests itself in the classroom. Secondly, to investigate whether classes with a high level of student participation should be categorized as teacher-directed or student-focused. Thirdly, to take note of teachers' activities in classes with a high level of student participation. The researchers analyzed 130 in-field class descriptions in nine upper secondary schools, drawn from the project Upper Secondary School Practices, collected during the years 2013-2014. Each class session was analyzed either as having a high level of student participation or failing to reach a required standard of student participation; the requirement being that $75 \%$ of students participate in teacher-directed work $75 \%$ of class time. Eighty-three class sessions were found to reach this standard.

Student academic engagement in these classes was analyzed through a variety of activities, here termed engagement indicators. These were 11 indicators listed here in frequency order (number of sessions in parentheses): working on assignments (69), directing questions to the teacher (65), showing signs of paying attention such as listening and following what is going on (46), discussing classroom tasks (44), working together on assignments (39), answering the teacher's questions on the subject 38), asking the teacher for assistance (35), writing and taking notes (21), showing interest in various ways (19), searching for and using materials (15), and reading aloud or silently (9). At least two indicators appeared in a class, and a maximum of nine appeared in a single session. On average five indicators appeared in a class session.

We also looked at the use of teacher-directed and student-focused teaching methods, which turned out to be almost an equal number in our sample of 83 classes, with only 11 that could not be labelled either teacher-directed or student-focused. In the sample, student class engagement remained more or less equal regardless of whether teacher- 
-directed or student-focused methods were used. The exceptions were indicators of paying attention, more often found in classes where teacher-directed methods were used, and indicators of searching for and using materials and working together on assignments, more often found in classes where student-focused methods were used.

Furthermore, the results indicate that the teacher's activities positively influence student engagement. Thus, the attributes of a positive demeanor, an atmosphere of warmth, clear instructions from the teacher, and the teacher's motivating manner were identified in $90 \%$ of classes with a high level of student engagement. There was a significant positive correlation between a teacher's positive demeanor and an atmosphere of warmth on the one hand and clear instructions on the other.

The study has its strengths and limitations. Although carefully selected, one-hundred-and-thirty class sessions is not a high ratio of all upper secondary school classes. A group of 15 researchers gathered the material. To ensure more accuracy they frequently met to discuss how they would perform the observations, and in $44 \%$ of the cases two researchers observed the session. It would have been interesting to compare class sessions with a high level of participation and those with lower levels. However, much fewer sessions did not reach our standard of $75 \%$ of students participating in teacher-directed work $75 \%$ of class time, and in some cases descriptions were not accurate enough to determine whether the level of participation reached our standards.

These findings can have implications for teacher education, both in university classrooms and in practicums where students can be trained to use methods likely to engage students in classroom work. Furthermore, they can be trained in some helpful tasks such as how to learn the names of their students and give clear instructions. Overall, the study also reminds us that teachers need to be mindful of their attitudes to students and the teaching methods they select in order to ensure students' academic engagement.

Key words: upper secondary schools, student participation, engagement, teaching methods, teachers' attitudes

\section{Um höfundana}

Hafrún Hafliðadóttir (hafrun@krikaskoli.is) starfar sem umsjónarkennari í Krikaskóla í Mosfellsbæ. Hún lauk BA-gráđu í sálfræđi frá Háskólanum á Akureyri 2016 og MS-gráđu í menntun framhaldsskólakennara við Háskóla Íslands 2019. Lokaverkefni hennar snerist um að skoða pátttöku og virkni í námi, með sérstaka áherslu á mikilvægt hlutverk kennara.

Elsa Eiríksdóttir (elsae@hi.is)er dósent við Menntavísindasvið Háskóla Íslands. Hún lauk BA-gráđu í sálfræđi frá Háskóla Íslands 1999 og meistara- og doktorsprófi í verkfræðilegri sálfræði 2007 og 2011 frá Georgia Institute of Technology. Rannsóknir hennar hafa helst snúið að hugrænum ferlum í námi, yfirfærslu pekkingar og færni, verklegu námi og starfsnámi.

Ingólfur Ásgeir Jóhannesson (ingo@hi.is) er prófessor við Menntavísindasvið Háskóla Íslands. Hann lauk bakkalárprófi í sagnfræði og uppeldisfræði 1979, námi til kennsluréttinda 1980 og cand.mag.-prófi í sagnfræði 1983 frá Háskóla Íslands, og doktorsprófi í menntunarfræðum frá Wisconsin-háskóla, Madison, 1991. Sérsvið hans eru námskrár, framhaldsskólar, menntastefna og kynjafræði í menntarannsóknum. 


\section{About the authors}

Hafrún Hafliðadóttir (hafrun@krikaskoli.is) teaches at Krikaskóli, an elementary school in Mosfellsbær. She completed a BA degree in psychology from the University of Akureyri in 2016 and an MS degree in psychology teaching from the University of Iceland in 2019. Her thesis comprised research on classroom engagement and the important role of the teacher.

Elsa Eiríksdóttir (elsae@hi.is) is an associate professor at the University of Iceland, School of Education. She completed a BA degree in psychology from the University of Iceland in 1999 as well as a master's degree and a PhD in engineering psychology from Georgia Institute of Technology in Atlanta in 2007 and 2011, respectively. Her research interests include learning, transfer of training, skill acquisition, and vocational education and learning.

Ingólfur Ásgeir Jóhannesson (ingo@hi.is) is a professor at the School of Education, University of Iceland. He completed his BA degree in history and educational studies in 1979, a post-graduate diploma for a teaching certificate in 1980, a cand.mag. degree in history in 1983, all from the University of Iceland, and a PhD degree in curriculum and instruction from the University of Wisconsin in 1991. His research focuses on curriculum, upper secondary schools, education policy, and gender and education.

\section{Heimildir}

Al-Hendawi, M. (2012).Academic engagement of students with emotional and behavioral disorders: Existing research, issues, and future directions. Emotional and Behavioural Difficulties, 17(2), 125-141. doi:10.1080/ 13632752.2012.672861

Appleton, J.J., Christenson, S. L. og Furlong, M.J. (2008). Student engagement with school. Critical conceptual and methodological issues of the construct. Psychology in the Schools, 45(5), 369-386. doi:10.1002/pits.20303

Appleton, J. J., Christenson, S. L., Kim, D. og Reschly, A. L. (2006). Measuring cognitive and psychological engagement:Validation of the student engagement instrument. Journal of School Psychology, 44(5), 427-445.

Bempechat, J. og Shernoff, D. J. (2012). Parental influences on achievement motivation and student engagement. Í S. L. Christenson, A. L. Reschly og C. Wylie (ritstjórar), Handbook of research on student engagement (bls. 315-342). New York: Springer.

Bolinger, K. og Warren, W. J. (2007). Methods practiced in social studies instruction: A review of public school teachers' strategies. International Journal of Social Education, 22(1), 68-84. Sótt af https://eric.ed.gov /?id=EJ779674

Braičić, Z., Đuranović, M. og Klasnić, I. (2014). Teaching and learning methods and practices in science and social study lessons. Croatian Journal of Education, 17(1), 83-95. doi:10.15516/cje.v17i0.1524

Burden, P. R. og Byrd, D. M. (2016). Methods for effective teaching: Meeting the needs of all students. Boston: Pearson.

Corrodi, V. C., Vogt, F. og Heim, D. K. (2019, ágúst). The relation between self-regulation and self-reported versus observed participation during class [fyrirlestur fluttur á ráðstefnu European Association for Research on Learning and Teaching, Aachen Dýskalandi].

Cuban, L. (2007). Hugging the middle:Teaching in an era of testing and accountability, 1980-2005. Education Policy Analysis Archives, 15(1), 1-29. Sótt af https://eric.ed.gov/?id=EJ800818 
DiPerna, J. C., Volpe, R. J. og Elliott, S. N. (2001). A model of academic enablers and elementary reading/ language arts achievement. School Psychology Review, 31(3), 298-312.

Dunleavy, J. og Milton, P. (2009). What did you do in school today? Exploring the concept of student engagement and its implications for teaching and learning in Canada. Toronto: Canadian Education Association (CEA).

Fisher, D. (2009). The use of instructional time in the typical high school classroom. The Educational Forum, 73(2), 168-176. Sótt af https://eric.ed.gov/?id=EJ834863

Fredricks, J. A., Blumenfeld, P. C. og Paris, A. H. (2004). School engagement: Potential of the concept, state of the evidence. Review of Educational Research, 74(1), 59-109. doi:10.3102/00346543074001059

Fredricks, J.A. og McColskey,W. (2012). The measurement of student engagement: A comparative analysis of various methods and student self-report instruments. Í S. L. Christenson, A. L. Reschly og C. Wylie (ritstjórar), Handbook of research on student engagement (bls. 763-782). New York: Springer.

Freiberg, H.J. og Driscoll, A. (2000). Universal teaching strategies (3. útgáfa). Needham Heights: Allyn \& Bacon.

Gerður G. Óskarsdóttir [o.fl.] (2014). Starfshættir í grunnskólum - meginniðurstöður og umræða. Í Gerður G. Óskarsdóttir (ritstjóri), Starfshattir í grunnskólum við upphaf 21. aldar (bls. 323-347). Reykjavík: Háskólaútgáfan.

Gerður G. Óskarsdóttir og rannsóknarhópur um starfshætti í framhaldsskólum. (2018). Starfshættir í framhaldsskólum: Aðdragandi og framkvæmd rannsóknar 2012-2018. Sérrit Netlu 2018 - Framhaldsskólinn í brennidepli. Sótt af http://netla.hi.is/serrit/2018/framhaldskolinn_brennidepli/01.pdf

Gettinger, M. og Seibert, J. K. (2002). Contributions of study skills to academic competence. School Psychology Review, 31(3), 350-365.

Greenwood, C. R., Carta, J. J., Kamps, D., Terry, B. og Delquadri, J. (1994). Development and validation of standard classroom observation systems for school practitioners: Ecobehavioral assessment systems software (EBASS). Exceptional Children, 61(2), 197-210.

Greenwood, C. R., Horton, B. T. og Utley, C. A. (2002). Academic engagement: Current perspectives on research and practice. School Psychology Review 31(3), 328-349.

Greenwood, C. R., Terry, B., Marquis, J. og Walker, D. (1994). Confirming a performance-based instructional model. School Psychology Review, 23(4), 625-668.

Hafsteinn Karlsson. (2009). Kennsluaðferðir í íslenskum og finnskum grunnskólum. Netla - Veftímarit um uppeldi og menntun. Sótt af http://netla.hi.is/greinar/2009/001/index.htm

Hattie,J. (2009). Visible learning: A synthesis of over 800 meta-analyses relating to achievement. London: Routledge.

Ingvar Sigurgeirsson. (2013). Litróf kennsluaðferðanna: Handbók fyrir kennara og kennaraefni (2. útgáfa). Reykjavík: Iðnú.

Ingvar Sigurgeirsson, Elsa Eiríksdóttir og Ingólfur Ásgeir Jóhannesson. (2018). Kennsluaðferðir í 130 kennslustundum í framhaldsskólum. Sérrit Netlu 2018 - Framhaldsskólinn í brennidepli. Sótt af http://netla. hi.is/serrit/2018/framhaldskolinn_brennidepli/09.pdf

Institute on Community Integration. (2006). High school SSESS study: Classroom observation. Sótt af https:// ici.umn.edu/beacons/pdf/ssess_pdf/hs/techreport3.pdf

Juuti, K., Lavonen, J., Uitto,A., Byman, R. og Meisalo,V. (2010). Science teaching methods preferred by grade 9 students in Finland. International Journal of Science and Mathematics Education, 8(4), 611-632. doi:10.1007/ s10763-009-9177-8

Kristjana Stella Blöndal og Sigrún Aðalbjarnardóttir. (2012). Student disengagement in relation to expected and unexpected educational pathways. Scandinavian Journal of Educational Research, 56(1), 85-100. doi:10 $.1080 / 00313831.2011 .568607$

Kristjana Stella Blöndal og Sigrún Aðalbjarnardóttir. (2016). Farsæl skólaganga ungmenna og páttur foreldra. Í Guðrún Kristjánsdóttir, Sigrún Aðalbjarnardóttir og Sóley S. Bender (ritstjórar), Ungt fólk: Tekist á við tilveruna (bls. 231-246). Reykjavík: Hið íslenska bókmenntafélag.

Li,Y. og Lerner, R. M. (2011). Trajectories of school engagement during adolescence: Implications for grades, depression, delinquency, and substance use. Developmental Psychology, 47(1), 233-247. doi:10.1037/a0021307

Li,Y., Lynch, A. D., Kalvin, C., Liu, J. og Lerner, R. M. (2011). Peer relationships as a context for the development of school engagement during early adolescence. International Journal of Behavioral Development, 35(4), 329-342. doi:10.1177/0165025411402578 
Mennta- og menningarmálaráđuneytið. (2011). Ađalnámskrá framhaldsskóla 2011. Almennur hluti. Reykjavík: Höfundur.

Murdock, T. B. (1999). The social context of risk: Status and motivational predictors of alienation in middle school. Journal of Educational Psychology, 91(1), 62-75. doi:10.1037/0022-0663.91.1.62

Pianta, R. C., Belsky, J., Houts, R. og Morrison, F. (2007). Opportunities to learn in America's elementary classrooms. Science, 315(5820), 1795-1796. doi:10.1126/science.1139719

Pianta, R. C., Steinberg, M. S. og Rollins, K. B. (1995). The first two years of school:Teacher-child relationships and deflections in children's classroom adjustment. Development and Psychopathology, 7(2), 295-312. doi:10.1017/S0954579400006519

Reyes, M. R., Brackett, M. A., Rivers, S. E., White, M. og Salovey, P. (2012). Classroom emotional climate, student engagement, and academic achievement. Journal of Educational Psychology, 104(3), 700-712. doi: $10.1037 / \mathrm{a} 0027268$

Roorda, D. L., Koomen, H. M.Y., Spilt, J. L. og Oort, F. J. (2011). The influence of affective teacher-student relationship on students' school engagement and achievement: A meta-analytic approach. Review of Educational Research, 81(4), 493-529. doi:10.3102/0034654311421793

Rosenfeld, L. B., Richman, J. M. og Bowen, G. L. (2000). Social support networks and school outcomes:The centrality of the teacher. Child and Adolescent Social Work, 17(3), 205-226. doi:10.1023/A:1007535930286

Rumberger, R.W. (2004). Why students drop out of school. Í G. Orfield (ritstjóri), Dropouts in America: Confronting the graduation rate crisis (bls. 131-155). Cambridge: Harvard Education Press.

Schmidt, J. A., Rosenberg, J. M. og Beymer, P. N. (2018). A person-in-context approach to student engagement in science: Examining learning activities and choice. Journal of Research in Science Teaching, 55(1), 19-43. doi:10.1002/tea.21409

Sheppard, S. (2011). School engagement: A ‘danse macabre'? Journal of Philosophy of Education, 45(1), 111-123. doi:10.1111/j.1467-9752.2010.00782.x

Sigrún Aðalbjarnardóttir. (2016). Seigla ungmenna - Dróun og staða pekkingar. Í Guðrún Kristjánsdóttir, Sigrún Aðalbjarnardóttir og Sóley Bender (ritstjórar), Ungt fólk:Tekist á við tilveruna (bls. 161-184). Reykjavík: Hið íslenska bókmenntafélag.

Sinatra, G. M., Heddy, B. C. og Lombardi, D. (2015). The challenges of defining and measuring student engagement in science. Educational Psychologist, 50(1), 1-13. doi:10.1080/ 00461520.2014.1002924

Skinner, E. A. og Belmont, M. J. (1993). Motivation in the classroom: Reciprocal effect of teacher behavior and student engagement across the school year. Journal of Educational Psychology, 85(4), 571-581.

Spanjers, D. M., Burns, M. K. og Wagner,A. R. (2008). Systematic direct observation of time on task as a measure of student engagement. Assessment for Effective Intervention, 33(2), 120-126. doi:10.1177/1534508407311407

Svanhildur Kr. Sverrisdóttir, Ragnheiður Margrét Guðmundsdóttir og Sigurlína Davíðsdóttir. (2011). Úttekt á ílenskukennslu í framhaldsskólum. Reykjavík: Mennta- og menningarmálaráðuneytið.

Taylor, L. og Parsons, J. (2011). Improving student engagement. Current Issues in Education, 14(1), 1-33. Sótt af https://cie.asu.edu/ojs/index.php/cieatasu/article/view/745

Voelkl, K. E. og Frone, M. R. (2000). Predictors of substance use at school among high school students. Journal of Educational Psychology, 92(3), 538-592. doi:10.1037/0022-0663.92.3583

Hafrún Hafliðadóttir, Elsa Eiríksdóttir og Ingólfur Ásgeir Jóhannesson. (2019).

Pátttaka nemenda í kennslustundum í framhaldsskólum á Íslandi.

Netla - Veftímarit um uppeldi og menntun. Menntavísindasvið Háskóla Íslands

Sótt af http://netla.hi.is/serrit/2019/menntakvika_2019/02.pdf

DOI: https://doi.org/10.24270/serritnetla.2019.43 